\title{
A Case Study of Mosaic Trisomy 13 in a 2-year-old Filipino Child
}

\author{
Carmencita D. Padilla, ${ }^{1,2}$ Patrick Jose D. Padilla, ${ }^{3}$ Lourdes Bernadette S. Tanchanco, ${ }^{4}$ \\ Myrian R. de la Cruz ${ }^{2}$ and Edsel G. Salonga ${ }^{2}$ \\ ${ }^{1}$ Department of Pediatrics, College of Medicine and Philippine General Hospital, University of the Philippines Manila \\ ${ }^{2}$ Institute of Human Genetics, National Institutes of Health, University of the Philippines Manila \\ ${ }^{3}$ Department of Obstetrics and Gynecology, College of Medicine and Philippine General Hospital, University of the Philippines Manila \\ ${ }^{4}$ Ateneo School of Medicine and Public Health
}

\begin{abstract}
Mosaic trisomy 13 is estimated to occur in $5 \%$ of all trisomy 13 cases. Presentation of trisomy 13 mosaicism is highly variable, with cases that may present with a normal phenotype and intellectual function, to cases with grossly abnormal features and profound developmental delays. We present a 2-year-old female with trisomy 13 mosaicism, who presented with small for gestational age (SGA), polydactyly, ventricular septal defect (VSD), and poor oral feeding.
\end{abstract}

Key Words: trisomy 13, mosaic trisomy 13, genetic counseling, SNP array

\section{INTRODUCTION}

Complete trisomy 13, or more commonly known as Patau syndrome, occurs when three copies of chromosome 13 are present in every cell. ${ }^{1}$ The incidence has been estimated at 1:5000 to $1: 20,000$ live births, the risk of which increases with advanced maternal age. ${ }^{1-3}$ This genetic disorder affects a variety of organ systems, including the central nervous system, cardiopulmonary system, urogenital system, and musculoskeletal system, among others. ${ }^{2}$ It is characterized by the triad of microphthalmia or anophthalmia, cleft lip and palate, and postaxial polydactyly, and also associated most commonly with midline defects, such as holoprosencephaly, omphalocele, and single umbilical artery. ${ }^{3}$ Prognosis has been known to be generally poor, with a median survival time between 7 and 10 days, with $86 \%$ to $91 \%$ of liveborn patients not surpassing the first year of life. ${ }^{2,4}$ Patients with trisomy 13 who live beyond the first year of life have been found to have profound developmental delay, among other abnormalities. ${ }^{5}$

In cases of mosaic trisomy 13, only a certain percentage of cells contain an extra chromosome 13. It is estimated that mosaicism occurs in 5\% of all trisomy 13 cases. ${ }^{6}$ Presentation of trisomy 13 mosaicism is highly variable, with cases that may present with a normal phenotype and intellectual function, to cases with grossly abnormal features and profound developmental delays. ${ }^{6}$ It has been noted, however,

Corresponding author: Carmencita D. Padilla, MD, MAHPS Institute of Human Genetics National Institutes of Health

University of the Philippines Manila

Pedro Gil St., Ermita, Manila 1000, Philippines

Email: cdpadilla@up.edu.ph that there is a poor correlation between the percentage of cells with an additional copy of chromosome 13 and the clinical features of the patient. ${ }^{6}$

Counseling parents of a fetus with trisomy 13 mosaicism remains difficult because of the phenotypic variability 
associated with the condition; some patients exhibit the typical phenotype of complete trisomy 13 with very poor prognosis while others have few dysmorphic features and prolonged survival. ${ }^{7}$

We present a case of a female with trisomy 13 mosaicism, who presented with SGA, polydactyly, VSD, and poor oral feeding.

\section{CLINICAL CASE}

$\mathrm{AB}$ (not her true initials) was born full term, 37 weeks age of gestation, to a 28-year-old primigravid mother via an unremarkable vaginal delivery, with an APGAR score of 8,9. Prenatal course was uncomplicated, with regular prenatal check-ups. Her birth weight was 2,200 grams (3$10 \%)$, small for gestational age (SGA), with a length of $44 \mathrm{~cm}(10 \%)$ and a head circumference of $32 \mathrm{~cm}(10-50 \%)$. The patient was admitted to the NICU for hypoglycemia due to poor oral feeding and SGA.

At birth, the patient was pink. She was normocephalic, with fontanelles soft and flat, patent nares, palate intact and mucous membranes pink. She however had a tight frenulum and flat nasal bridge. Overall, she was nondysmorphic. On auscultation, she had clear breath sounds bilaterally with symmetric expansion. She had a normal heart rate with regular rhythm, with a $2 / 6$ early systolic murmur best heard at the mid left sternal border, radiating throughout the entire pericardium and both axillae. The diastole was clear. Her abdomen was soft, non-distended, with no hepatosplenomegaly or masses palpated. She had a normal female external genitalia. She had no hip clicks. However, a sacral dimple was noted. There was a post axial polydactyly on her left foot. Neurologic assessment showed age appropriate tone, with intact Moro, suck and grasp reflexes (Figure $1 \mathrm{~A}$ and $\mathrm{B}$ ).

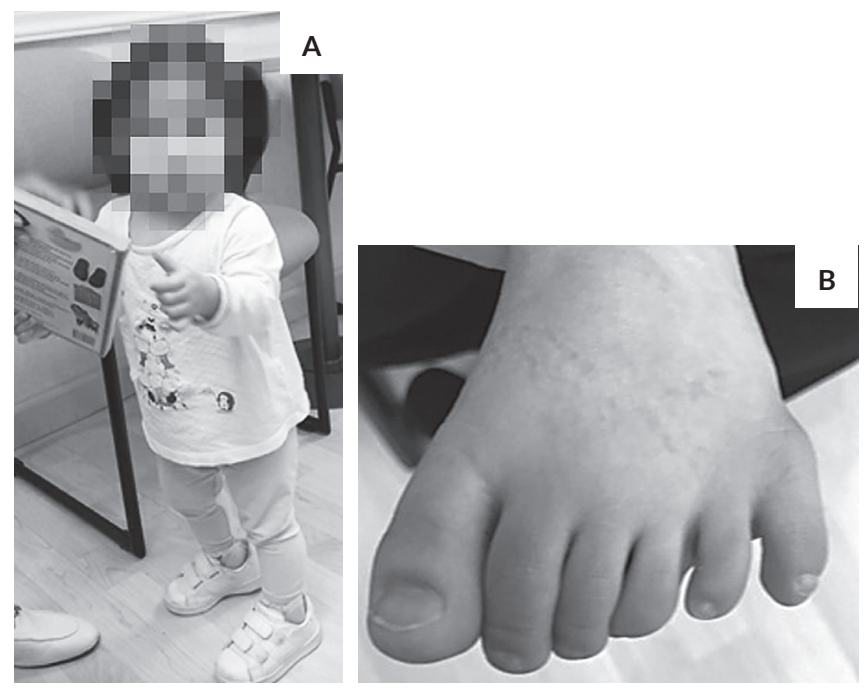

Figure 1. (A) $A B$ at 1 year 7 months old and (B) extra digit in $L$ foot.
Laboratory and imaging studies were done to investigate the poor oral feeding, SGA, heart murmur and extra digit on the foot. Blood and urine CMV cultures done were negative. Maternal and infant toxoplasmosis IgG were positive, but infant IgM was negative. Ophthalmologic exam demonstrated scattered bilateral retinal hemorrhages without evidence of chorioretinitis. Brain ultrasound also showed no evidence of congenital toxoplasmosis. Echocardiography revealed moderate to large perimembranous VSD with outlet extension, minimal RAE and RVE with RVH and septal flattening, normal RV function, and mild PPS. It also revealed normal LV size and function, as well as a tiny PFO with left to right flow. There was no evidence of congestive heart failure.

Since the overall features of the child did not fit a known syndrome malformation, a microarray analysis was done. SNP microarray analysis was performed using the Affymetrix Cytoscan HD platform which uses over 743000 SNP probes and $1953000 \mathrm{NPCN}$ probes with a median spacing of $0.88 \mathrm{~kb}$. The microarray result [arr (hg19) (13)x2-3] revealed a mosaic gain of whole chromosome 13. The whole genome SNP microarray analysis has detected mosaicism for trisomy 13 . The 2.25 copy number dosage observed in the array is equivalent to $25 \%$ of the nucleated blood cells (primarily granulocytes) being positive for trisomy 13.

Ultrasound of the spine showed low position of the conus at L3, with other findings unremarkable. Renal ultrasound revealed normal kidney size and overall echogenicity, mild fullness of the collecting systems, the left greater than the right but without overt hydronephrosis, and three small cysts in the right kidney, with the largest measuring $2.5 \mathrm{~mm}$. Liver ultrasound was unremarkable.

Patient was discharged after 31 days of neonatal care in a hospital in the US and returned to the Philippines for continuing care. In Manila, the medical team included a geneticist, developmental pediatrician, cardiologist, nephrologist, ophthalmologist, neurologist and a team of therapists including a physical therapist, occupational therapist and early childhood specialist.

Karyotyping was performed to rule out a Robertsonian translocation. The chromosomal studies of the patient revealed 47,XX,+13[10]/46,XX[90], confirming mosaic trisomy 13 (Figure $2 \mathrm{~A}$ and B). Parental karyotypes were done and revealed normal studies.

Surgical correction of the VSD at age 8 months was well tolerated. She is maintained on anticonvulsant medications because of the risk of seizures. Head circumference is being monitored and is normal. Her vision is being closely monitored especially with the observation of a head tilt and occasional left eye esotropia.

Early intervention was initiated at $2^{\text {nd }}$ month of age. She currently receives physical and occupational therapy and attends an early intervention program. She has ageappropriate mobility skills to explore her environment 

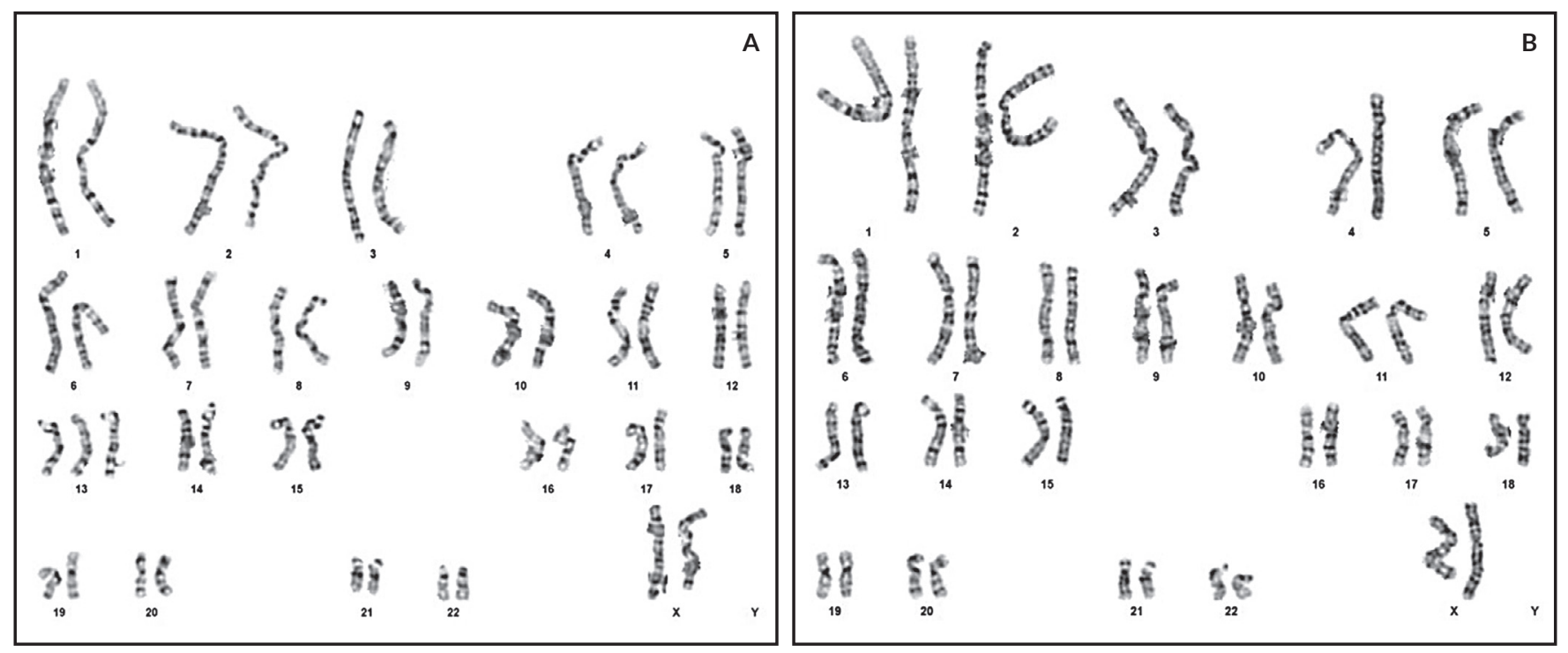

Figure 2. Chromosomal results 47,XX,+13[10]/46,XX[90]. (A) karyotype showing the trisomy 13 and (B) karyotype showing normal results.

independently and has good motor planning skills. She is attempting to do higher balance activities. Grasping and object manipulation are within age-expected range. She is able to engage in pretend play and turn taking. She understands one-step commands and gestures to indicate her needs. She has around 5-10 specific words in her vocabulary. Her developmental profile using the Bayley Scales of Infant Toddler Development $-3^{\text {rd }}$ edition is as shown in Table 1.

\section{DISCUSSION}

Imataka, et al. reported survival past the first year of life in twelve patients with trisomy 13 including four with trisomy 13 mosaicism. ${ }^{2}$ The oldest survivor with a full trisomy 13 was a 32 -year-old female, ${ }^{8}$ and the oldest survivor with a trisomy 13 mosaicism was a 38-year-old male. ${ }^{9}$

Table 2 presents the reported phenotype of patients diagnosed with mosaic trisomy 13 . Only patients with original diagnosis of Trisomy D and further re-evaluated as Trisomy 13 by Giemsa stain or FISH are included. The review reveals the wide variability of the clinical phenotype and lifespan. ${ }^{6} 10-14$ Two patients had fair to good developmental outcomes. Our patient (10\% trisomy 13 in peripheral blood and $25 \%$ in array studies) had cognitive performance of 19 months at a chronological age of 24 months. Another patient ${ }^{6}$ with $10 \%$ mosaicism had normal developmental milestones at age 5 years old. In both cases, chromosomal studies were done blood samples only.

Review of cases have shown that trisomy 13 mosaicism patients with typical features of a complete trisomy 13 had poorer prognosis that led to death in the neonatal period in contrast with patients with less dysmorphic features who had prolonged survival. ${ }^{1}$ Other factors that affect prognosis are involvement of vital structures (heart or the central nervous system), degree of the malformation, association with midline facial clefts. ${ }^{4}, 15$ Life expectancy of patients with trisomy 13 has also been affected by the aggressiveness of the medical care given., ${ }^{3,4}$ Although literature reports that children with full trisomy 13 usually have profound intellectual disability, ${ }^{4}$ there are some individuals who may have mild intellectual disability. ${ }^{16}$

The Cytogenetics laboratory at the Institute of Human Genetics, National Institutes of Health, University of the Philippines Manila reports 4 cases (including this patient) of mosaic trisomy 13 among 104 patients with various types of trisomy presented in Table 3.

Table 1. Developmental profile using the Bayley Scales of Infant and Toddler Development - $3^{\text {rd }}$ Edition (BSID-III) taken at 24 months and 7 days old

\begin{tabular}{|c|c|c|c|c|}
\hline Index & Scaled Score & Composite Score & Descriptive Category & Estimated Age Equiv. \\
\hline Cognitive & 7 & $85(78-94)$ & Low Average & 19 months \\
\hline Language & $\begin{array}{l}\text { Receptive: } 7 \\
\text { Expressive: } 6 \\
\text { Total: } 13\end{array}$ & $79(73-88)$ & Borderline & $\begin{array}{l}\text { Receptive: } 19 \text { months } \\
\text { Expressive: } 17 \text { months }\end{array}$ \\
\hline Motor & $\begin{array}{l}\text { Fine motor: } 5 \\
\text { Gross motor: } 9 \\
\text { Total: } 14\end{array}$ & $82(76-91)$ & Low Average & $\begin{array}{l}\text { Fine: } 15 \text { months } \\
\text { Gross: } 21 \text { months }\end{array}$ \\
\hline
\end{tabular}


Table 2. Clinical and laboratory findings of patients with mosaic trisomy 13

\begin{tabular}{|c|c|c|c|c|}
\hline & Imataka G et al & Fogu G, et al & Cowen & Singh \\
\hline Age at reporting & 7 yrs 4 mos & $12 \mathrm{yrs}$ & $9 \mathrm{yrs}$ & 22 yrs \\
\hline Birth History & $\begin{array}{l}39 \text { wks } \\
3366 \mathrm{~g} \\
+ \text { asphyxia } \\
\end{array}$ & $\begin{array}{l}32 \text { wks } \\
1420 \mathrm{~g} \\
\text { no mention of asphyxia }\end{array}$ & $\begin{array}{l}- \\
3350 \mathrm{~g} \\
\text { no mention of asphyxia }\end{array}$ & $\begin{array}{l}\text { full term } \\
3400 \mathrm{~g} \\
\text { no mention of asphyxia }\end{array}$ \\
\hline \multicolumn{5}{|l|}{ Dysmorphic Features } \\
\hline Microcephaly & no mention & microcephaly & microcephaly & microcephaly \\
\hline Head and Face & $\begin{array}{l}\text { frontal alopecia, capillary } \\
\text { hemangioma in forehead, } \\
\text { high arched narrow } \\
\text { V shaped palate }\end{array}$ & $\begin{array}{l}\text { dolichocephalyhemangioma } \\
\text { in scalp, prominent sutures, } \\
\text { sloping forehead, long } \\
\text { eyelashes, long smooth } \\
\text { philtrum, micrognathia, } \\
\text { thin upper lip, short lingual } \\
\text { frenulum downslanting } \\
\text { palpebral fissures, broad flat } \\
\text { nose, high arched palate }\end{array}$ & $\begin{array}{l}\text { exomphalos } \\
\text { flat nose, and bilateral } \\
\text { microphthalmia and } \\
\text { colobomata }\end{array}$ & $\begin{array}{l}\text { flattened occiput, sloping } \\
\text { forehead, short neck, } \\
\text { high arched palate }\end{array}$ \\
\hline Eye and Ear anomalies & no mention & low set ears & $\begin{array}{l}\text { low set ears } \\
\text { microphthalmia } \\
\text { cataract } \\
\text { coloboma bilateral, }\end{array}$ & microphthalmia \\
\hline Genital anomalies & $\begin{array}{l}\text { cryptorchidism } \\
\text { penis palmatus }\end{array}$ & no mention & $\begin{array}{l}\text { ambiguous genitalia } \\
\text { at birth } \\
\text { micropenis }\end{array}$ & hypoplastic penis \\
\hline Limb anomalies & narrow fingernails & $\begin{array}{l}\text { flexion deformity, } \\
\text { camptodactyly of } 3^{\text {rd }} \text { and } 4^{\text {th }} \\
\text { fingers, hypoplasia of distal } \\
\text { phalange of the } 5^{\text {th }} \text { finger R, } \\
\text { clubfoot, adduct metatarsus, } \\
\text { hallux valgus, overlapping } \\
\text { toes, cubitus valgus }\end{array}$ & $\begin{array}{l}\text { Polydactyly, fingers } \\
\text { clenched with overriding } \\
\text { thumbs. Hyperconvex } \\
\text { narrow finger nails, } \\
\text { polydactyly, fingers } \\
\text { clenched with overriding } \\
\text { narrow finger nails }\end{array}$ & $\begin{array}{l}\text { deformed claw hands; } \\
\text { abnormally placed thumbs, } \\
\text { clinodactyly of } 5^{\text {th }} \text { digit, } \\
\text { abnormal toes; equinovarus } \\
\text { talipes; dysplastic hips }\end{array}$ \\
\hline Cognitive Development & severe MR & no mention & severe MR & severe MR \\
\hline
\end{tabular}

\begin{tabular}{|c|c|c|c|c|}
\hline Other medical problems & $\begin{array}{l}\text { VSD } \\
\text { Seizures, recurrent } \\
\text { infections (respiratory, } \\
\text { urinary) }\end{array}$ & $\begin{array}{l}\text { recurrent infections } \\
\text { (urinary), seizures, phylloid } \\
\text { hypomelanosis }\end{array}$ & $\begin{array}{l}\text { ASD } \\
\text { R kidney absent }\end{array}$ & $\begin{array}{l}\text { recurrent infections } \\
\text { (chest, eye, and ear) }\end{array}$ \\
\hline Laboratory Results & $\begin{array}{l}47, \mathrm{XY},+13 \text { (G-banding } \\
\text { karyotype); } \\
47, \mathrm{XY},+13(73.2 \%) / \\
47, \mathrm{XY}(\mathrm{FISH}) ;\end{array}$ & $\begin{array}{l}\text { Birth blood sample } \\
\text { Iso (13q) 51\%, large der (13) } \\
49 \% \\
\text { Skin } \\
\text { Iso (13q) } 12 \% \text {, large der (13) } \\
88 \% \\
9 \text { years, blood } \\
\text { Iso (13q) } 74.14 \% \text {, large der } \\
\text { (13) } 25.86 \% \\
\text { Skin } \\
\text { large der (13) } 71 \% \\
\text { small der (13) } 29 \% \\
\end{array}$ & $\begin{array}{l}47, \mathrm{XY},+13(88 \%) / 46, \mathrm{XY} \\
(9 \%) \text { blood sample in } 1969 ; \\
47, \mathrm{XY},+13(99 \%) / 46, \mathrm{XY} \\
(1 \%) \text { in blood sample in } \\
1977 ; \\
47, \mathrm{XY},+13(92 \%) / 46, \mathrm{XY} \\
(7 \%) \text { in skin sample in } 1977\end{array}$ & $\begin{array}{l}\text { Trisomy D chromosome } \\
\text { in 1978; } \\
\text { Reinvestigation showed } 47 \text {, } \\
X Y,+13(97 \%) / 46, X Y(3 \%)\end{array}$ \\
\hline Parental karyotypes & & & & $\begin{array}{l}\text { "Analysis of mother's } \\
\text { chromosomes revealed an } \\
\text { entirely normal D Group } \\
\text { Karyotype" }\end{array}$ \\
\hline
\end{tabular}

Legend: MR mental retardation; CHD congenital heart disease; VSD ventricular septal defect; ASD atrial septal defect; PDA patent ductus arteriosus 
Kunwar

Delatycki and Gardner

Delatycki and Gardner

Delatycki and Gardner

This patient

24 yrs

5 yrs

$10 \mathrm{yrs}$

3 yrs 6 mo

2 yrs old

$2200 \mathrm{~g}$

41 wks

no mention of asphyxia

$3500 \mathrm{~g}$

$2640 \mathrm{~g}$

-

$37 \mathrm{wks}$

no mention of asphyxia

no mention of asphyxia

no mention of asphyxia

no asphyxia

microcephaly

no mention

no mention

no mention

HC $32 \mathrm{~cm}$ (10-50\%)

high arched palate, short columella, enlarged nares,

Low posterior hairline

no mention

no mention

non-dysmorphic

bifid tongue, smooth

philtrum, microtia, thin

upper lip vermillion,

dental malocclusion,

mandibular prognathia

low set ears

no mention

no mention

no mention

occasional L eye esotropia

no mention

no mention

no mention

no mention

none

broad fingertip,

no mention

no mention

no mention

post axial polydactyly

broad hallux

(a)

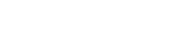

(a)

no mention

ASD

probably with CHD due

to presence of cyanosis

during crying

seizures

47, XY, +13 (25\%)/46,XY

(75\%) blood sample

Interphase FISH on blood

showed Trisomy 13 in

blood (15\%) and buccal

mucosa cells (6\%)

PDA

nomention

46,XX,rob(13;13) (ql0;q10) [14\%]/46,XX in blood;

$10 \%$ in skin fibrobalsts

At 2 yrs 4 mos, $47, X Y,+13$
$(20 \%) / 46, X Y(80 \%)$ in
blood;
Repeat blood karyotyping
at 10 years and $40 \%$ with
Trisomy 13 .

amniocentesisrevealed 1 culture with46,XX; 1 culture with $7 / 50$ cells with $47, X X+13$ and 1 culture with $47, X X+22$ in $5 / 50$ cells.

Fetal sampling at 17 weeks had $100 / 100$ with $46, X X$

Cord blood sample at birth, 3/100 had Trisomy 13
At 24 months, cognitive is $19 \mathrm{mo}$; receptive language 19 mos; expressive language $17 \mathrm{mos}$; fine motor 15 mos; gross 21 months VSD S/P surgery at 8 mos hydronephrosis, small cysts in R kidney

$47, X X,+13[10] / 46, X X[90]$

microarray result [arr (hg19) (13)x2-3] revealed a mosaic gain of whole chromosome 13 
Table 3. Trisomy 13 at the Institute of Human Genetics, National Institute of Health from 1991-2017

\begin{tabular}{|c|c|}
\hline & $\mathbf{N}$ \\
\hline \multicolumn{2}{|l|}{ Full Trisomy 13} \\
\hline $47, X X,+13$ & 44 \\
\hline $47, X Y,+13$ & 50 \\
\hline Subtotal & 94 \\
\hline \multicolumn{2}{|l|}{ Mosaic trisomy 13} \\
\hline $47, X X,+13 / 46, X X$ & 3 \\
\hline $47, X X,+13 / 47, X Y,+15$ & 1 \\
\hline Subtotal & 4 \\
\hline \multicolumn{2}{|c|}{ Robertsonian Translocation Trisomy 13} \\
\hline $46, X X,+13, \operatorname{der}(13 ; 13)(q 10 ; q 10)$ & 2 \\
\hline 46,XX,+13,der(13;14)(q10;q10) & 3 \\
\hline 46,XY,+13,der(13;14)(q10;q10) & 1 \\
\hline Subtotal & 6 \\
\hline Total & 104 \\
\hline
\end{tabular}

Several papers have reported there is no clear association between the level of mosaicism, the severity of the phenotype and potential survival at birth. Griffith et al. reported a patient with normal neurodevelopmental outcome with $40 \%$ trisomic cells in leukocytes and $45 \%$ of trisomic cells in fibroblasts. ${ }^{1,3}$ In some studies, it has also been noted that the percentage of abnormal cells decrease over time, and might be possibly due to a natural selection against the abnormal cells. ${ }^{3,5,6,9}$

Diagnosis is a challenge among patients with mosaicism. Our patient did not have the classical features of trisomy 13. Microarray testing was done because of non-specific findings of SGA, polydactyly, VSD, and poor oral feeding. Parental G-banded karyotypes revealed normal studies. Genetic counseling is difficult knowing that prognosis will be unpredictable.

Two large studies have addressed the origin of trisomy 13 using microsatellites and demonstrated that the majority of cases are maternal in origin, with almost equal meiosis I and II errors as well as markedly reduced recombination but only 2 cases of mosaic trisomy 13 were included. SNP array provides both genotype and copy number information and is useful in studying mechanisms of complex mosaic aneuploidy and UPD. ${ }^{17}$

In a study of chromosome mosaicism in 22,000 amniocenteses, $\mathrm{Hsu}$ et al. found true chromosome mosaicism in 50 cases $(0.27 \%)$, including two cases of mosaic trisomy $13 .{ }^{18}$ Robinson et al. found that the majority of cases of mosaic trisomy 13 were associated with trisomic fertilization compatible with a meiotic origin of the extra chromosome and with postzygotic loss of one chromosome. ${ }^{19}$ Mosaic trisomy 13 at amniocentesis has been reported to be associated with normal or near-normal liveborn. Delatycki and Gardner reported two cases of mosaic trisomy 13 at amniocentesis with a favorable outcome. One case with level II mosaic trisomy 13 was normal at age 3 years and 6 months, and the other case with level II mosaic trisomy 13 was normal at age 17 months. ${ }^{6}$ Di Giacomo et al. reported a case of mosaic trisomy 13 at amniocentesis with a favorable outcome. The child was normal with no dysmorphic features at age two years. ${ }^{20}$ The mother of our patient did not undergo prenatal diagnosis.

Our patient continues to develop within normal range, albeit borderline skills in her language and fine motor development. The close follow up on our patient will provide a better picture on the future outcome of the patient.

\section{CONCLUSION}

This paper reported a female patient who presented with SGA, polydactyly, VSD, and poor oral feeding, wherein microarray and chromosomal analysis revealed trisomy 13 mosaicism. Counseling remains to be an important part of management, with emphasis on continued follow-up to monitor the progress of the patient, as well as to be able to refer to the necessary services to improve and maximize the quality of life.

For patients with minor dysmorphic features, microarray studies have shown to be useful for resolution of diagnosis. For patients with mosaicism, they will benefit from further studies on skin fibroblasts to better assess the level of mosaicism as this information will be important for long term outcome.

\section{Acknowledgment}

We thank the family of the patient for allowing us to share the story and pictures of $\mathrm{AB}$ with the medical and allied medical professions.

\section{Statement of Authorship}

All authors participated in data collection and analysis, and approved the final version submitted.

\section{Author Disclosure}

All authors declared no conflicts of interest.

\section{Funding Source}

None.

\section{REFERENCES}

1. Griffith CB, Vance GH, Weaver DD. Phenotypic variability in trisomy 13 mosaicism: Two new patients and literature review. Am J Med Genet A. 2009 Jun; 149A(6):1346-58.

2. Imataka G, Hagisawa S, Nitta A, Hirabayashi H, Suzumura H, Arisaka O. Long-term survival of full trisomy 13 in a 14-year-old male: a case report. Eur Rev Med Pharmacol Sci. 2016 Mar; 20(5):919-22.

3. Hsu HF, Hou JW. Variable expressivity in Patau syndrome is not all related to trisomy 13 mosaicism. Am J Med Genet A. 2007 Aug 1; 143A(15):1739-48.

4. Peroos S, Forsythe E, Pugh JH, Arthur-Farraj P, Hodes D. Longevity and Patau syndrome: what determines survival? BMJ Case Rep. 2012 Dec 6; 2012:bcr0620114381. doi: 10.1136/bcr-06-2011-4381. 
5. Chen M, Yeh GP, Shih, JC, Wang BT. Trisomy 13 mosaicism: study of serial cytogenetic changes in a case from early pregnancy to infancy. Prenat Diagn. 2004 Feb; 24(2):137-43.

6. Delatycki M, Gardner RJ. Three cases of trisomy 13 mosaicism and a review of the literature. Clin Genet. 1997 Jun; 51(6):403-7.

7. Chen CP. Prenatal diagnosis and genetic counseling for mosaic trisomy 13. Taiwan J Obstet Gynecol. 2010 Mar; 49(1):13-22.

8. Tunca Y, Kadandale JS, Pivnick EK. Long-term survival in Patau syndrome. Clin Dysmorphol. 2001 Apr; 10(2):149-50.

9. Petit P, Fryns JP. Normal/trisomy 13 mosaicism in a 38-year-old male. Genet Couns. 1994; 5(3):311-4.

10. Imataka G, Yamanouchi H, Hirato J, Eguchi M, Kojima M, Honma $\mathrm{K}$, et al. Autopsy report of a 7-year old patient with the mosaic trisomy 13. Cell Biochem Biophys. 2013 Nov; 67(2):813-7.

11. Fogu G, Maserati E, Cambosu F, Moro MA, Poddie F, Soro G, et al. Patau syndrome with long survival in a case of unusual mosaic trisomy 13. Eur J Med Genet. 2008 Jul-Aug; 51(4):303-14.

12. Cowen JM, Walker S, Harris F. Trisomy 13 and extended survival. J Med Genet. 1979 Apr; 16(2):155-7.

13. Singh KS. Trisomy 13 (Patau's syndrome): a rare case of survival into adulthood. J Ment Defic Res. 1990 Feb; 34 (Pt 1):91-3.

14. Kunwar F, Pandya V, Bakshi SR. Constitutional mosaic trisomy 13 in two germ cell layers is different from Patau syndrome? A Case Report. J Clin Diagn Res. 2016 Mar; 10(3):GD03-5.
15. Zoll B, Wolf J, Lensing-Hebben D, Pruggmayer M, Thorpe B. Trisomy 13 (Patau syndrome) with an 11-year survival. Clin Genet. 1993 Jan; 43(1):46-50.

16. Nanjiani, A, Hossain A, Mahgoub N. Patau Syndrome. J Neuropsychiatry Clin Neurosci. 2007 Spring; 19(2):201-2.

17. Jinawath N, Zambrano R, Wohler E, Palmquist MK, Hoover-Fong J, Hamosh A, et al. Mosaic trisomy 13: understanding origin using SNP array. J Med Genet. 2011 May; 48(5):323-6.

18. Hsu LY, Kaffe S, Jenkins EC, Alonso L, Benn PA, David K, et al. Proposed guidelines for diagnosis of chromosome mosaicism in amniocytes based on data derived from chromosome mosaicism and pseudomosaicism studies. Prenat Diagn. 1992 Jul; 12(7):555-73.

19. Robinson WP, Binkert F, Bernasconi F, Lorda-Sanchez I, Werder EA, Schinzel AA. Molecular studies of chromosomal mosaicism: relative frequency of chromosome gain or loss and possible role of cell selection. Am J Hum Genet. 1995 Feb; 56(2):444-51.

20. Di Giacomo MC, Susca FC, Resta N, Bukvic N, Vimercati A, Guanti G. Trisomy 13 mosaicism in a phenotypically normal child: description of cytogenetic and clinical findings from early pregnancy beyond 2 years of age. Am J Med Genet A. 2007 Mar 1; 143A(5):518-20.

\section{The Acta Medica Philippina is now accepting limited advertising for its front and back cover (colored), as well as for available spaces in some of its pages, as appropriate. For inquiries and submission of proposals, please email us at actamedicaphilippina.upm@up.edu.ph}

